\title{
THE INFLUENCE OF EMPLOYER BRAND ON EMPLOYEES LOYALTY - THE MODERATOR EFFECT OF EMPLOYEES SATISFACTION
}

\author{
Goran Pavlović ${ }^{1}$ \\ Stefan Zdravković ${ }^{2}$
}

Received: June 23, 2019 / Revised: July 29, 2019/ Accepted: October 30, 2019

(C) Association of Economists and Managers of the Balkans, 2019

\begin{abstract}
The successful operation of the organization is not based exclusively on customer satisfaction, but it is necessary to ensure the satisfaction of all relevant stakeholders. For an organization, it is first of all important to provide value for its employees, as it will result in a greater degree of their satisfaction, loyalty and productivity, which further leads to value creation for consumers. Companies are making significant efforts to build a unique image in order to present it as a unique and desirable place to work, which can also be defined as an employer brand. The main goal of the paper is to determine whether the employer brand has a positive impact on employee satisfaction and loyalty. The results showed that the employer brand has a significant impact on employee satisfaction and loyalty, and that satisfaction has a positive moderator role.
\end{abstract}

Keywords: Employer Brand, Employee Satisfaction, Employee Loyalty, Human Resources

\section{JEL Classification M12 - M51}

This paper was presented at the Fifth International Scientific Conference on Knowledge Based Sustainable Development - ERAZ 2019 - May 23, Budapest, Hungary, www.eraz.org.rs

Goran Pavlović

pavlovic.g90@gmail.com

1 PhD student, University of Kragujevac, Faculty of Economics, Đure Pucara Starog 3, 34000 Kragujevac, Serbia

2 PhD student, University of Kragujevac, Faculty of Economics, Đure Pucara Starog 3, 34000 Kragujevac, Serbia 


\section{INTRODUCTION}

Modern business conditions are characterized by the fact that consumers are in the epicenter of all marketing activities. The goal of each company is to deliver to the consumer a product that will fully meet its wishes and needs. In this way, the consumer achieves a certain degree of satisfaction and over time becomes loyal. In addition to consumers, it is important for every company that its employees are satisfied with their work and, over time, they become loyal to the company. In today's business environment, which can be characterized as a knowledge-based era, human resources are key factor to achieving competitive advantage, and therefore companies are trying to attract the best talents from the labor market. As a result, the integration of marketing disciplines and human resource management has become necessary. By the synthesis of these two disciplines, the employer brand arises, which can be understood as the entirety of the company's effort to identify, attract and motivate employees at the workplace (Ambler and Barrow, 1996; Berthon, Ewing and Hah, 2005). Human capital created in this way can be viewed as a valuable resource that is unique and difficult to imitate and substitute, which enables the creation of a sustainable competitive advantage. In order to build the employer brand, it is necessary to follow the principles of branding and internal marketing, which implies such working conditions in which there are good interpersonal relations, a creative and challenging task, the possibility of promotion, acquisition of additional knowledge, competitive earnings, flexible working hours, etc. Bearing in mind the above, the main goal of this paper is to point out the influence of the employer brand on employee satisfaction and loyalty. Accordingly, the subject of the work is represented by employees in companies operating in the territory of the Republic of Serbia.

\section{LITERATURE REVIEW}

Employer brand arises by applying marketing philosophy in HRM, that is, applying the principles of internal marketing and branding in the HRM discipline (Ambler and Barrow, 1996). Companies that are oriented towards their employees apply the concept of internal marketing, which includes programs designed for employees and their development. It is focused on finding, motivating and retaining employees oriented towards the consumer (Domazet, 2011). The main goals of internal marketing are: 1) successful fulfillment of all the business obligations by the employees in the function of achieving the goals of the company, 2) motivation of employees to perform the tasks as experts who are oriented towards the consumer and focused on the quality of the product or service, and 3) attraction and retention of competent personnel.

Employer brand can be defined as the "package of functional, economic and psychological benefits provided by employment and identified with the employing company" (Ambler and Barrow, 1996). It is about the overall effort of the company to create such working conditions that will attract and retain the best employees (Alniaçik et al., 2014; Ewing et al., 2002). In other words, the employer brand represents the company's aspiration to present itself as a unique and desirable place to work (Sokro, 2012). Functional, economic and psychological benefits provided by employment authors Berthon et al (2005) modify and expand, thus creating a set of five large groups of benefits, which they name the employer brand dimensions. These dimensions are interest value (interesting working environment, application of innovative work methods, respect for ideas and creativity of employees), social value (satisfied employees, good interpersonal relations, etc), economic value (high salaries, bonuses, material incentives), development value (training, career advancement, gaining additional experience, etc) and applied value (application of acquired knowledge, teaching others, good treatment by management, etc). These dimensions served to the development of the so-called EmpAt scale, which is often used in researching the employer brand 
in practice. As a result of the application of the employer brand numerous benefits arise, such as a good working environment, a positive image in the public, increase in profitability, and the employees themselves receive competitive wages, learning opportunities, work in a stimulating environment, etc (Pavlović and Slavković, 2018). Two factors that the employer brand can influence are especially important, and these factors consequently affect many other factors of the company, primarily its performance. Those are employee's satisfaction and loyalty

Satisfaction is defined as the individual state of mind resulting from the comparison of the observed results of a product or service with the expectation of that person (Castillo-Canalejo and Rio-Jimber, 2018). Satisfaction with the job represents the employee's positive attitudes towards the job he/she performs, which arises as a result of satisfied needs, desires and fulfilled expectations of the employee at the workplace (Aziri, 2011). In other words, it is a total employee satisfaction for the employers (Davies, Mete and Whelan, 2018). Factors that lead to satisfaction with the job can be numerous, with the most often being in mind the compensation system, the characteristics of the job, working conditions, the leadership style, interpersonal relations, the possibility of promotion, etc (Janićijević, Kovačević and Petrović, 2015). The employer brand can provide these factors and thus ensure the enthusiasm, positive attitudes and emotions of employees, increase their motivation and productivity (Davies, Mete and Whelan, 2018; Khanolkar, 2014; Aziri, 2011). Khanolkar (2014) has found that there is a significant direct positive relationship between the employer brand and employee satisfaction, and accordingly, the following hypothesis can be defined:

\section{$\mathbf{H}_{1}$ : The employer brand has a statistically significant positive impact on employees satisfaction.}

As one of the key benefits of employee satisfaction is the creation of psychological attachment, that is, loyalty to the company. The concept of loyalty to the company has three forms: affective, continuous and normative loyalty. In practice, most attention is paid to affective loyalty, which can be understood as a strong emotional association of the employee with the company due to significant identification and feeling of belonging to it (Tanwar, 2017). According to affective loyalty, the employees identify their own goals and value system with the company's goals, value system and culture, feel a high level of affiliation in the company, which leads to reduced fluctuation, absenteeism, growth of motivation and increased business performance. This corresponds with some of the dimensions of the employer brand that can significantly impact on employee loyalty, such as high salaries, opportunities for promotion, learning, good interpersonal relationships, working conditions etc (Vaijayanthi, Shreenivasan and Roy, 2011). Authors Allan and Meyer (1990), Alshathry, Clarke and Goodman (2017), Yalim and Mizrak (2017) and Vaijayanthi, Shreenivasan and Roy (2011) have found that there is a significant direct positive relationship between the employer brand and employee loyalty, and accordingly, the following hypothesis can be defined:

\section{$\mathbf{H}_{2}$ : The employer brand has a statistically significant positive impact on employees loyalty.}

If the employees are satisfied with their work, they will become loyal to the company over time. Loyalty in the context of an employee can be defined as the strength of an individual's identification and involvement in a particular organization (Roelen, Koopmans and Groothoff, 2008). Authors (Yalim and Mizrak, 2017) have found that satisfaction moderates the influence of the employer brand on loyalty, and accordingly, the following hypothesis can be set:

$\mathbf{H}_{3}$ : Employee satisfaction has a significant moderator role in relation to the employer brand and employees loyalty. 


\section{METHODOLOGY}

The research was conducted in the period from May 10 to June 10, 2019. The sample comprised 59 respondents, who were segmented according to certain demographic characteristics. The survey was carried out personally and electronically by survey method. The main condition that respondents could participate in the research was to be employed. Regarding the demographic characteristics of the respondents, there are 24 women and 35 men in the total sample of 59 examinees. The largest number of respondents is aged 21 to $30(66.1 \%)$. When it comes to education, the majority of respondents have higher education (57.6\%). Structural information analysis showed that most respondents worked in companies with up to 50 employees $(33.9 \%)$ and in companies with 51 to 150 employees (35.6\%). When it comes to the form of company ownership, the majority of respondents work in domestic private companies - 22 (37.3\%), then in state enterprises - 20 (33.9\%) and finally in foreign private companies - 17 (28.8\%).

In order to examine the influence of the employer brand on the satisfaction and loyalty of employees, an empirical research was conducted. A questionnaire was used to collect data, which was segmented into two parts. The first part of the questionnaire was designed with the goal of respondents to express their views on the employer brand, as well as to assess their degree of satisfaction and loyalty to the company. For this purpose, the adopted findings were taken from the relevant papers in this field: (Berthon, Ewing and Hah, 2005; Tanwar, 20171; Allan and Meyer, 1990). The findings are taken from the above papers because they have a high degree of reliability. Respondents gave answers via Likert scale and expressed the degree of agreement with a certain statement from grades 1 to 7 (1 - absolutely disagree; 7 - absolutely agree). The second part of the questionnaire is designed to determine the demographic characteristics of the respondents, as well as structural information about the companies in which respondents work. Data processing was performed using the statistical software "SPSS v.20".

\section{RESEARCH RESULTS}

At the beginning of the statistical analysis, values of arithmetic means and standard deviations were calculated. Table 1 shows the results of arithmetic means and standard deviations for the statements related to the employer brand variable.

The respondents expressed the most favorable and the most homogeneous attitudes on the basis of the statement "The organization produces high-quality products and services" (arithmetic mean $=5.59$ and standard deviation $=1.06$ ). On the other hand, respondents expressed the most unfavorable and least homogeneous attitudes on the basis of the statement "Humanitarian organization - gives back to society" (arithmetic mean $=4.20$ and standard deviation $=2.02$ ). It can be concluded that the companies in which the respondents work mainly produce products and services of a high quality level, and that there is a considerable deviation when it comes to the participation of companies in humanitarian actions, where only a small number of companies take part. Table 2 shows the results of arithmetic mean and standard deviations for the findings related to the employee satisfaction variable. 
Table 1. Results of descriptive statistics for employer brand Source: Authors

\begin{tabular}{|l|c|c|}
\hline Statements & AM & SD \\
\hline Recognition / appreciation from management & 5,23 & 1,37 \\
\hline A fun working environment & 4,89 & 1,59 \\
\hline A springboard for future employment & 4,96 & 1,58 \\
\hline Feeling good about yourself as a result of working for a particular organization & 5,16 & 1,38 \\
\hline Feeling more self-confident as a result of working fora particular organization & 5,30 & 1,18 \\
\hline Gaining career-enhancing experience & 5,49 & 1,31 \\
\hline Having a good relationship with your superiors & 5,05 & 1,35 \\
\hline Having a good relationship with your colleagues & 5,13 & 1,50 \\
\hline Supportive and encouraging colleagues & 5,08 & 1,22 \\
\hline Working in an exciting environment & 5,01 & 1,49 \\
\hline Innovative employer - novel work practices/forward-thinking & 4,61 & 1,38 \\
\hline The organization both values and makes use of your creativity & 4,86 & 1,43 \\
\hline The organization produces high-quality products and services & $\mathbf{5 , 5 9}$ & $\mathbf{1 , 0 6}$ \\
\hline The organization produces innovative products and services & 4,87 & 1,30 \\
\hline Good promotion opportunities within the organization & 5,06 & 1,55 \\
\hline Humanitarian organization - gives back to society & $\mathbf{4 , 2 0}$ & $\mathbf{2 , 0 2}$ \\
\hline Opportunity to apply what was learned at a tertiary institution & 5,18 & 1,37 \\
\hline Opportunity to teach others what you have learned & 5,19 & 1,31 \\
\hline Acceptance and belonging & 5,06 & 1,20 \\
\hline The organization is customer-orientated & 5,28 & 1,17 \\
\hline Job security within the organization & 5,15 & 1,67 \\
\hline Hands-on inter-departmental experience & 5,00 & 1,51 \\
\hline Happy work environment & 5,40 & 1,10 \\
\hline An above average basic salary & 4,74 & 1,52 \\
\hline An attractive overall compensation package & 4,71 & 1,64 \\
\hline
\end{tabular}

Table 2. Results of descriptive statistics for employee satisfaction Source: Authors

\begin{tabular}{|l|c|c|}
\hline \multicolumn{1}{|c|}{ Statements } & AM & SD \\
\hline Generally speaking, I am satisfied with my work. & 5,25 & 1,33 \\
\hline I am satisfied with the time limits within which I have to finish my work. & 5,30 & 1,57 \\
\hline I am satisfied with the amount of work I have to do. & 4,94 & 1,55 \\
\hline I am satisfied with the variation of my work tasks. & 4,79 & 1,44 \\
\hline I am satisfied with the working conditions. & 5,01 & 1,66 \\
\hline I am satisfied with working hours. & 5,00 & 1,69 \\
\hline I am satisfied with the salary. & 4,74 & 1,52 \\
\hline I am satisfied with the relationship with my superiors. & 5,32 & $\mathbf{1 , 1 2}$ \\
\hline I am satisfied with the relationship with my colleagues. & 4,98 & 1,34 \\
\hline I am satisfied with the instructions given for carrying out my work tasks. & 5,27 & 1,27 \\
\hline My job is physically demanding. & $\mathbf{3 , 4 2}$ & $\mathbf{1 , 7 5}$ \\
\hline My job is mentally challenging. & 5,27 & 1,43 \\
\hline I have the freedom to carry out my work tasks. & 5,22 & 1,28 \\
\hline I am involved in making decisions at work. & 5,11 & 1,39 \\
\hline $\begin{array}{l}\text { Training and education at work positively influence my perspective in a further } \\
\text { career. }\end{array}$ & $\mathbf{5 , 4 0}$ & 1,41 \\
\hline
\end{tabular}


The lowest value of the arithmetic mean based on the statement "My job is physically demanding" (3.42) shows that the respondents do not invest too much physical effort in doing business activities. But on the basis of the stated conclusion, there are also major differences in the responses of the respondents, since the value of the standard deviation is the highest (1.75). The respondents showed the highest level of satisfaction on the basis of the statement "Training and education at work positively influence my perspective in a further career" (the highest value of the arithmetic mean $=5.40$ ), which means that companies invest in human capital or development of employees, because in that way they acquire a competitive advantage in a business environment that can be characterized as a knowledge-based era. Respondents expressed the most homogeneous attitudes on the basis of the statement "I am satisfied with the relationship with my superiors" (the lowest value of standard deviation $=1.12$ ). Table 3 shows the results of arithmetic means and standard deviations for the findings related to the loyalty of employees variable.

Table 3. Results of descriptive statistics for employee loyalty Source: Authors

\begin{tabular}{|l|c|c|}
\hline Statements & AM & SD \\
\hline I would be very happy to spend the rest of my career with this organization. & 4,88 & $\mathbf{1 , 9 0}$ \\
\hline I enjoy discussing my organization with people outside it & $\mathbf{5 , 0 8}$ & $\mathbf{1 , 6 3}$ \\
\hline I really feel as if this organization's problems are my own & $\mathbf{4 , 2 2}$ & 1,81 \\
\hline $\begin{array}{l}\text { I think I cannot easily tie up to another company,like this one I'm currently } \\
\text { working on. }\end{array}$ & 4,52 & 1,72 \\
\hline I feel like a "part of the family" in this company. & 4,47 & 1,68 \\
\hline I feel the emotional attachment with this company. & 4,48 & 1,70 \\
\hline This organization has a great deal of personal meaning for me. & 4,72 & 1,67 \\
\hline I feel highly affiliated with this company. & 4,81 & 1,68 \\
\hline
\end{tabular}

The respondents expressed the most favorable and the most homogeneous attitudes on the basis of the statement "I enjoy discussing my organization with people outside it" (arithmetic mean = 5,08 and standard deviation $=1,63$ ). Respondents expressed the most unfavorable attitudes on the basis of the statement "I really feel as if this organization's problems are my own" (the lowest value of the arithmetic mean is 4.22). Respondents answers mostly deviate from the statement "I would be very happy if I spent the rest of my career in this company" (the highest value of standard deviation is 1.90), which means that a some of respondents would spend the rest of their career in certain company, and the rest would not.

Few authors often point out that it is appropriate to use partial least squares to examine psychological variables and models, especially in the case of an insufficiently developed theoretical understanding of the impact of an independent variable on a dependent variable, like in this paper (Aparicio, 2011). Bearing in mind the above, for examining the hypothesis SmartPLS v.3 statistical package was used. Research model is shown on Figure 1.

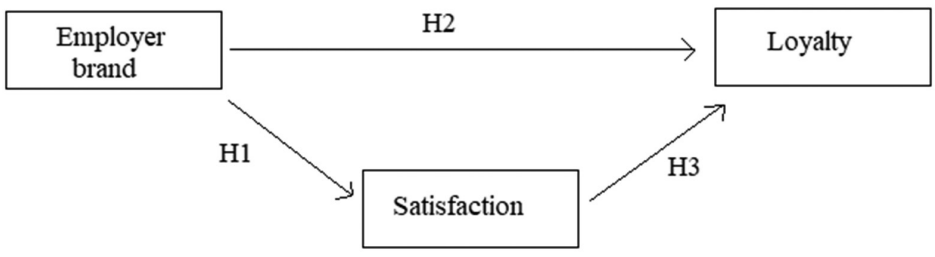

Figure 1. Research model

Source: Authors 
Prior to implementing SEM, through reliability and confirmatory factor analysis the suitability of the overall model fit was determined. In order for the model to be considered reliable, it is necessary that its value of the Cronbach Alpha coefficient has minimum value 0,7 (Nunnally, 1978), while Composite Reliability (CR) must be minimum 0,7 (according to some authors 0,9) (Hair et al., 2014). Results are shown in Table 4.

Table 4. Reliability analysis

Source: Authors

\begin{tabular}{|l|c|c|}
\hline Variable & Cronbachs alpha & Composite Reliability \\
\hline Employer brand & 0,914 & 0,925 \\
\hline Loyalty & 0,923 & 0,937 \\
\hline Satisfaction & 0,866 & 0,897 \\
\hline
\end{tabular}

Since all values are greater than the minimum prescribed values, it can be concluded that there is good reliability of the statements used to measure the model variables. When we talk about confirmatory factor loading, Average Variance Extracted (AVE) is in some cases less than 0,5, which is defined as the threshold. However, as the authors Fornell and Larcker (1981) stated, this is not a problem if the previous value of the Composite Reliability was in all cases above 0,6 . In the research model there is no problem of multicollinearity, since the variables have the value of the VIF factor (Variance Inflation Factor) less than 5 (Field, 2000) (Employer brand = 3,6, Loyalty $=3,6$ and Satisfaction $=3,8)$. Finally, the value of $\chi 2 / \mathrm{df}$ test has to be less than 3 (Byrne, 1998). The value obtained in the model is 2.8 , so it can be stated that the research model is achieving the good adequacy.

Using the SEM analysis, the statistical significance of the tested effects was calculated. The results of the analysis are shown in Table 5.

Table 5. Reliability analysis

Source: Authors

\begin{tabular}{|l|c|c|}
\hline Hypothesis & $\begin{array}{c}\text { Standardized } \\
\text { beta coefficient }\end{array}$ & p value \\
\hline Employer brand $\rightarrow$ Satisfaction & 0,898 & 0,000 \\
\hline Employer brand $\rightarrow$ Loyalty & 0,123 & $0,056^{*}$ \\
\hline Employer brand $\rightarrow$ Satisfaction $\rightarrow$ Loyalty & 0,759 & 0,000 \\
\hline
\end{tabular}

Results of the SEM analysis has shown the employer brand has a statistically significant positive impact on employee satisfaction $(\beta=0,989, \mathrm{p}=0,000)$, which confirms the $\mathrm{H}_{1}$ hypothesis. With a risk of error of 0.1 it can be stated that the employer brand has a statistically significant positive impact on employees' loyalty $(\beta=0,123, p=0,056)$. The specificity of the results when examining the second hypothesis is reflected in the fact that after the test of the moderator variation there was a change in the value of the test. Namely, the result of the test of the influence of the employer brand on the loyalty of employees before the inclusion of a moderator verified at the level of 0,000, with a beta coefficient of 0,782 . However, after including on the moderator variable, there is a decrease in the beta coefficient value and $p$ value, where the beta coefficient in the new iteration is significantly lower, and the test value is at the level of less than 0.1. But this is not a problem, first of all because it can still be argued that the employer brand has a statistically significant positive impact on employees' loyalty, which has confirmed the $\mathrm{H}_{2}$ hypothesis. But these results 
also confirm the last hypothesis. Namely, when examining the influence of the employer brand on the loyalty of employees with satisfaction as a moderator variable, it has been shown that there is a significant increase in the value of the beta coefficient and $p$ value, and consequently it can be argued that the employee satisfaction has a significant moderator role in the relationship of the employer brand and loyalty of the employees $(\beta=0.759, \mathrm{p}=0.000)$, which confirms the $\mathrm{H}_{3}$ hypothesis. In addition, it should be emphasized that the predictor variables describe a total of $80.6 \%$ of the variability of the dependent variable, ie employee loyalty $\left(\mathrm{R}^{2}=0,806\right)$.

\section{DISCUSSION AND CONCLUSION}

Within the basic research model, the influence of the employer brand on the satisfaction and loyalty of the employees was analyzed. The results of the SEM analysis show that the employer brand has a positive statistically significant impact on employee satisfaction, which confirmes $\mathrm{H}_{1}$ hypothesis. The results are similar to those of previous research that proved that there is a positive impact of the employer brand on employee satisfaction (Yalim and Mizrak, 2017; Khanolkar, 2014). Also, the results of the SEM analysis show that the employer brand has a positive statistically significant influence on employees loyalty, thus confirming $\mathrm{H}_{2}$ hypothesis. The results obtained are similar to the results of previous research, which have established a positive link between the employer brand and employees loyalty (Vaijayanthi, Shreenivasan and Roy, 2011; Tanwar, 2017). Satisfaction is included in the research model as a moderator variable. The results show that satisfaction has a positive significant moderator role in relation to the employer brand and employees loyalty, which confirms $\mathrm{H}_{3}$ hypothesis. The obtained results confirmed the claim of the previous research that satisfaction moderated the influence of the employer brand on loyalty. We can conclude that the strengthening of the satisfaction strengthens the attitude of the employer brand and loyalty.

Theoretical implications can be derived from the analysis of the relationship of the variables of the observed model. Confirmed hypotheses also represent the theoretical implications of work, as they expand the scientific knowledge about the influence of the employer brand on the satisfaction and loyalty of the employees. The managerial implications of the work are reflected in the help of the owners of companies in the examination of factors that influence the satisfaction and loyalty of the employees. The employer brand and internal marketing considerably influence the satisfaction and loyalty of employees, who are then more motivated and create superior value for consumers, which also affects the satisfaction and loyalty of consumers, and ultimately allows the company to make profitable long-term business. The limitation of work is primarily related to the sample, i.e. its size and structure. In future work, apart from increasing sample size, research should be carried out to ensure the individual participation of different groups in the sample. In addition, research should be carried out more often.

\section{ACKNOWLEDGEMENT}

This work is supported by the project of the Ministry of Education of Science and Technological Development under the title "Application of modern methods of management and marketing in improving the competitiveness of enterprises in Serbia in the process of its integration into the European Union”. Registration number of the project OI 179062. 


\section{REFERENCES}

Allan, N.T., \& Meyer, J.P. (1990). The measurement and antecedents of affective, continuance and normative commitment to the organization. Journal of Occupational Psychology, 63, 1-18. doi:10.1111/j.2044-8325.1990.tb00506.x

Alniaçik, E., Alniaçik, U., Erat, S., \& Akçin, K. (2014). Attracting talented employees to the company: Do we need different employer branding strategies in different cultures? $8^{\text {th }}$ International Strategic Management Conference, Procedia - Social and Behavioral Conference, 150, 336-344. doi:10.1016/j.sbspro.2014.09.074

Alshathry, S., Clarke, M., \& Goodman, S. (2017). The role of employer brand equity in employee attraction and retention: a unified framework. International Journal of Organizational Analysis, 25(3), 413-431.doi:10.1108/IJOA-05-2016-1025

Ambler, T., \& Barrow, S. (1996). The employer brand. The Journal of Brand Management, 4(3), 185-206. doi:10.1057/bm.1996.42

Aparicio, G.M. (2011). Partial least squares (PLS) methods: origin, evolution and application i social sciences. Communications in Statistics - Theory and Methods, 40(13), 2305-2317. doi:10.1080/03610921003778225

Aziri, B. (2011). Job satisfaction: a literature review. Management Research and Practice, 3(4), 77-86.

Berthon, P. Ewing, M., \& Hah, L.L. (2005). Captivating company: dimensions of attractiveness in employer branding. International Journal of Advertising, 24(2), 151-172. doi:10.1080/02 650487.2005.11072912

Byrne, B. M. (1998). Structural equation modeling with LISREL,PRELIS, and SIMPLIS: Basic concepts, applications, and programming. Mahwah, NY: Lawrence Erlbaum.

Castillo-Canalejo, A.M., \& Rio-Jimber J.A. (2018). Quality, satisfaction and loyalty indices. Journal of Place Management and Development, 11(4), 428-446. doi:10.1108/JPMD-05-20170040

Davies, G., Mete, M., \& Whelan, S. (2018). When employer brand image aids employee satisfaction and engagement. Journal of Organizational Effectiveness: People and Performance, 5(1), 64-80. doi:10.1108/JOEPP-03-2017-0028

Domazet, I. (2011). Uloga internog marketinga u unapredjenju kvaliteta ljudskih resursa. In: Aktivne mere na tržištu rada i pitanja zaposlenosti. Beograd: Institut ekonomskih nauka. 260-279.

Ewing, M.K., Pitt, L.F., Bussy, N.M., \& Berthon, P. (2002). Employment branding in the knowledge economy. International Journal of Advertising, 21(1), 3-22. doi:10.1080/02650487.20 02.11104914

Field, A. (2000). Discovering statistics using SPSS for windows. Thousand Oaks: Sage Publications.

Fornell, C., \& Larcker, D.F. (1981). Evaluating structural equation models with unobservable variables and measurement error. Journal of Marketing Research, 18(1), 39-50. doi: $10.2307 / 3151312$

Hair, J.F., Hult, T.M., Ringle, C.M., \& Sarstedt, M. (2014). A primer on partial least squares structural equation modeling (PLS-SEM). Los Angeles: SAGE.

Janićijević, N. Kovačević, P., \& Petrović, I. (2015). Identifying organizational factors of job satisfaction: the case of one Serbian company. Economic Annals, 205, 73-104. doi:10.2298/ EKA1505073J

Khanolkar, R.S. (2014). Influence of employer branding on satisfaction and commitment of generation Y employees. IOSR Journal of Business and Management, 7th International Business Research Conference, Indian Education Society's Management College and Research Centre, 13-18. 
Nunnally, J.C. (1978). Introduction to psychological measurement. New York: McGraw-Hill.

Pavlović, G., \& Slavković, M. (2018). The preliminary research of employers brand development at enterprises in Serbia. International Scientific Conference, Contemporary Issues in Economics, Business and Management, EBM 2018, Kragujevac, 197-207.

Roelen, C.A.M., Koopmans, P.C., \& Groothoff, J.W. (2008). Which work factors determine job satisfaction?, Work, 30(4), 433-439.

Sokro, E. (2012). Impact of employer branding on employee attraction and retention. European Journal of Business and Management, 4(18), 164-173.

Tanwar, K. (2017). The effect of the employer brand dimensions on organizational commitment: evidence from the Indian IT industry. Asia-Pacific Journal of Management, Research and Innovation, 12(3/4), 282-290. doi:10.1177/2319510X17701854

Vaijayanthi, P., Shreenivasan, K.A., \& Roy, R. (2011). Employer branding as an antecedent to organization commitment - An empirical study of manufacturing and service sector units. 2011 IEEE Colloquium on Humanities, Science and Engineering Research (CHUSER 2011), 969-974.

Yalim, F., \& Mizrak, K.C. (2017). A field study on the relationship between employer brand and employee satisfaction. International Review of Management and Marketing, 7(2), 92-103. 